\title{
Guidelines for the choosing of river interventions considering environmental, archaeological and landscaping constraints
}

\author{
L. de Santoli ${ }^{1}$, A. Monaco ${ }^{1}$ \& F. Cinquepalmi ${ }^{2}$ \\ ${ }^{1}$ Centro Interdipartimentale per il Territorio, l'Edilizia, \\ il Restauro e l'Architettura (CITERA), Rome University "La Sapienza", \\ Italy \\ ${ }^{2}$ Member of the National Technical Board of Marine Protected Areas of \\ the Italian Ministry for the Environment, Land and Sea Protection, Italy
}

\begin{abstract}
Bioengineering techniques can be used to treat erosion of riverbanks, for the recovery of degraded riparian areas providing appropriate vegetation, as well as for allowing natural processes to provide a sustainable vegetation cover on the treated sites of a river. The project's primary focus includes the elaboration of a guidelines manual for the planning of flood defence management and environmental or landscaping redevelopment interventions, using bioengineering techniques. The innovative aspect of this paper is that it offers different technical solutions according to the environmental, archaeological and landscaping constraints of an area. All the interventions are explained in a descriptive manual that analyses every kind of fluvial problem grouped together in technical data sheets that include description, suitable applications, materials, limitations, costs and impact level of each considered intervention. In addition, a diagram has been drawn up to make the choice of the best technique to use according to the present constraints easier. The manual, the data sheets and the diagram are correlated by means of specific cross-references in order to provide unambiguous information for the planning of interventions. The result is a useful instrument for the management of river basin interventions. By foreseeing more complex outlooks it offers a methodology that is applicable to different contexts.
\end{abstract}

Keywords: bioengineering, environmental constraint, archaeological constraint, landscaping constraint, river basin, flood defence, environmental redevelopment. 


\section{Introduction}

The growing attention that is being devoted to the fragile and vulnerable environmental value of river habitats has brought to the fore the need to preserve these riches, be they in a natural or urban context.

The main aim of this project is to develop a methodology for creating organic and versatile supports to help choose from the operative technologies available in river environments. These supports are organic because they are tightly linked, whilst remaining heterogeneous; and versatile because they can be easily applied to a variety of national and international scenarios.

The starting point was the creation of a database encapsulating all the different kinds of intervention available within a river context, privileging where possible those technologies that can be termed bioengineering techniques.

An initial classification covered the subdivision of flood defence works into streambank stabilization, breaking of banks defence, modelling the longitudinal or transversal shape of the river, the creation of flood retention basins. Works relating to a context of environmental and landscape requalification instead concern the creation of structures for the treatment of surface water, the rehabilitation of natural habitats, the creation of wetlands and the setting up of visual, acoustic and olfactory screens [2].

The study of the different types of intervention led to the creation of guidelines for the localisation and feasibility of different works along the river course in relation to the landscaping, environmental and archaeological restrictions present in each area.

The end result is the creation of a manual that includes descriptions of planned works, technical sheets of works and a diagram for outlining and differentiating all the gamut of technologies used. Once these instruments had been set up, a case study was chosen in order to test out the method. The chosen area will be mapped out, highlighting the most suitable works in a key related to the study.

\section{Types of work}

The two macro-areas including the totality of the works examined cover flood defence works as well as environmental and landscape requalification. Operative methods involving bioengineering techniques were given preference throughout most of the study.

Erosion control works consisted largely in providing a surface protection of the river banks against erosion from current, weather and runoff water. On steep slopes or erosion-prone soil, for example, grass acts as a powerful agent against erosion. Although the roots of the single plants are not particularly deep, a grasscovered slope absorbs well the kinetic energy of water and offers good conditions for the evolution of the ecosystem. With this in mind, a number of low impact techniques were examined. Priority was given to those that imply a total or partial use of organic materials, both as a substrata for the plants to take root and as an anchorage structure for the fiber rolls to the soil through the root 
network of plants. Examples include coir fiber rolls, brush mattress, erosion control blankets [3], geotexile coir mats, vegetated rock walls. For each kind of work, the study examined the degree of guaranteed erosion protection and its impact on the surrounding area [4].

Different kinds of longitudinal banks were considered for ensuring the hydraulic defence of land alongside rivers in plains. Mostly either in earth or brickwork, examined works also included alterations to existing banks with a view to completely changing their building structure.

While on the one hand the advantages and necessity of banks for protecting vast sections of land from flooding are clear, the constriction of a river's course within banks raises water levels in the event of extreme flood events and increases chances of damage from reduced drainage in surrounding land, a factor that can lead to permeations and damage to the groundwater [5]. Furthermore, the elimination of expansion areas increases the weight of swells in the valley sections of a river. Banks should be more than just defences against overflow: they should be made with sufficient technical know how to ensure that there is no danger of breakage because of siphoning effects. Essentially banks are artificial barriers made of earth, brick or wood for the containment of water. Generally they stand no shorter than 10-12 metres, to ensure that they are able to contain swells in the water and protect the land behind them from flooding. The function of banks is to avoid any contact between the river and the surrounding land, channelling the waters into a conveniently limited space [6].

Work to shape the canal involves redefining the river course. These are necessary when the canal needs dredging, to broaden the space available for swell waters to pass through. It generates the movement of river basin materials that can be placed or not in the same water course.

Two different kinds of work have been considered with regards to modifying longitudinal sections: check dams provoke an immediate lowering of the longitudinal slope of the water course, thereby diminishing the erosive effects and favouring the deposit of material. Contrary to check dams, sill do not emerge much from the canal and work to fix altimetry at a local level so that the bed cannot decrease and, in the event of erosion upstream, diminish sloping [4].

Flood retention basins, that may be placed in-line or off-line to the water course, enable the storage of water during extreme floods events. Once the event has passed the outflow may be regulated by an opening through which the piled volume of water is given back [7, 8].

The presence of a river in an area brings about a number of favourable naturalistic conditions, supports important ecosystems and, through the transport of sediments and the recharging of the groundwater, performs a number of particular hydrological 'tasks'. With its water, canal and banks the 'river system' constitutes a varied ensemble of habitats that support a high number of living organisms. In those situations where it is possible to guarantee security from hydrodynamic phenomena, these conditions must by preserved and safeguarded [9]. Environmental requalification works consist mainly in the setting up of plant barriers, which serve to reduce acoustic, visual and olfactory impact and the creation of wetlands. A number of goals can be achieved simultaneously through 
the recovery or creation of wetlands, chiefly: improvement of water quality through assimilation and transformation processes of nutrients and other polluting agents; attenuation of swell peaks and water storage; increasing the naturalistic value of a determined site through photosynthesis, greater animal life, greater biodiversity, the spread of these effects to neighbouring ecosystems; a social use for landscaping, recreational, business, didactic purposes; and the recharging of groundwater [10].

\section{Operative methodology}

Once the kinds of work had been outlined, the next step was to describe them in two different works collected in a manual. The first one illustrates the technologies used and the substantial differences between one work and the other, concentrating particularly on all the problems associated with planning and implementation on a more general, rather than specific, plane. The second work is instead made up of a series of technical cards that evaluate the feasibility of interventions in very particular contexts such as the ones listed above (antierosive, canal modelling etc). After a brief description, each work lists the applicability scope and the materials to be used in the event of there being specific restrictions in the relevant area. Each work is therefore accompanied by different building solutions depending on the individual context of restrictions, that influences impact level of materials used. Under the description of the brush mattress, for example, which comes under the antierosive category, biodegradable materials have been used for sheathing in the event of there being environmental restrictions; and low visual impact technologies in the event of there being archaeological remains, fig. 1 .

Further aid in choosing the most suitable work is provided by a diagram, that offers quick indications in function of the restrictions present, bearing in mind the need to achieve a condition of security. If two works offer the same degree of protection, this enables a choice based on the effects on the environment in question, fig. 2.

Once the study area has been pinpointed, the next step involves the mapping of the entire area according to the guidelines traced in the descriptive graphs, for a visual overview of the choice of different works to be carried out (flood defence or environmental and landscape requalification). In this case a cartographic software is necessary (Arcgis) to enable a hard copy and digital copy output.

\section{Results}

The various kinds of work are listed according to possible environmental, landscape and archaeological restrictions, factors that would entail a considerably increase in impact during the implementation phase.

In order to allow the implemented system to be consulted quickly a number of connections have been made between each single work. Each card containing a description of the work has been given a reference code that is immediately visible, fig. 3 . 
Materials utilized:

\begin{tabular}{|c|c|c|}
\hline $\begin{array}{l}\text { Presence of landscaping } \\
\text { constraint }\end{array}$ & $\begin{array}{l}\text { Presence of environmental } \\
\text { constraint }\end{array}$ & $\begin{array}{l}\text { Presence of archaeological } \\
\text { constarint }\end{array}$ \\
\hline $\begin{array}{l}\text { Wire mesh coated with zinc } \\
\text { rounding inert materials and } \\
\text { vegetal matters. Seeds by } \\
\text { hydroseeding }\end{array}$ & $\begin{array}{l}\text { Coir fiber rolls containing inert } \\
\text { materials and vegetal matters. } \\
\text { Seeds by hydroseeding }\end{array}$ & $\begin{array}{l}\text { Geotexile coir mats containing } \\
\text { inert materials and vegetal } \\
\text { matters. Seeds by hydroseeding }\end{array}$ \\
\hline
\end{tabular}

Figure 1: Detail of the technical card concerning brush mattress and the different choices for materials in function of constraints.

For example, for what concern the reshaping of banks, if these are in areas where constraints are present, the possibility of bringing about a moving back and going straight of the work has been taken into account, substituting brick works with works in earth, thereby allowing planting, so that the overall structure can be more easily inserted into a landscape.

As far as antierosion works are concerned, if there are areas during the river course that are not particularly prone to erosion, in the case of presence of an environmental constraint (such as a protected area) a good precautionary measure would be to insert a coir fiber roll made up entirely of biodegradable material rather than a vegetated rock wall or a geotexile coir mats, whose impact is certainly greater.

\section{Conclusions}

The results that have been obtained are a useful instrument of consultation for public administrations and local communities for planning works on rivers according to problems and restrictions governing particular areas. The method was tested on a section of the river Tiber between Rome and the Tyrrhenian Sea.

This area proved to be a particularly suitable case study in that it contains a large number of environmental and anthropic contexts with their respective environmental, archaeological and landscape restrictions.

The cartography of the area will be drawn up with the creation of shapefiles, with shapes and colours that are directly related to those used in the descriptions. The same symbology will be present in the diagram containing the subdivision of different kinds of work, thereby providing precise indications to help define the feasibility of works according to constraints present in each area. Consultation of the different works performed, highlighted the common line that affords an immediate visualisation and therefore makes it easy to choose the kind of technology that must be used in each situation. Furthermore for each kind of work different building solutions are foreseen depending on different impact of the materials utilized. The relation between the graphs tends to facilitate an integrated visualisation of the concepts, thereby favouring a cross-consultation. 


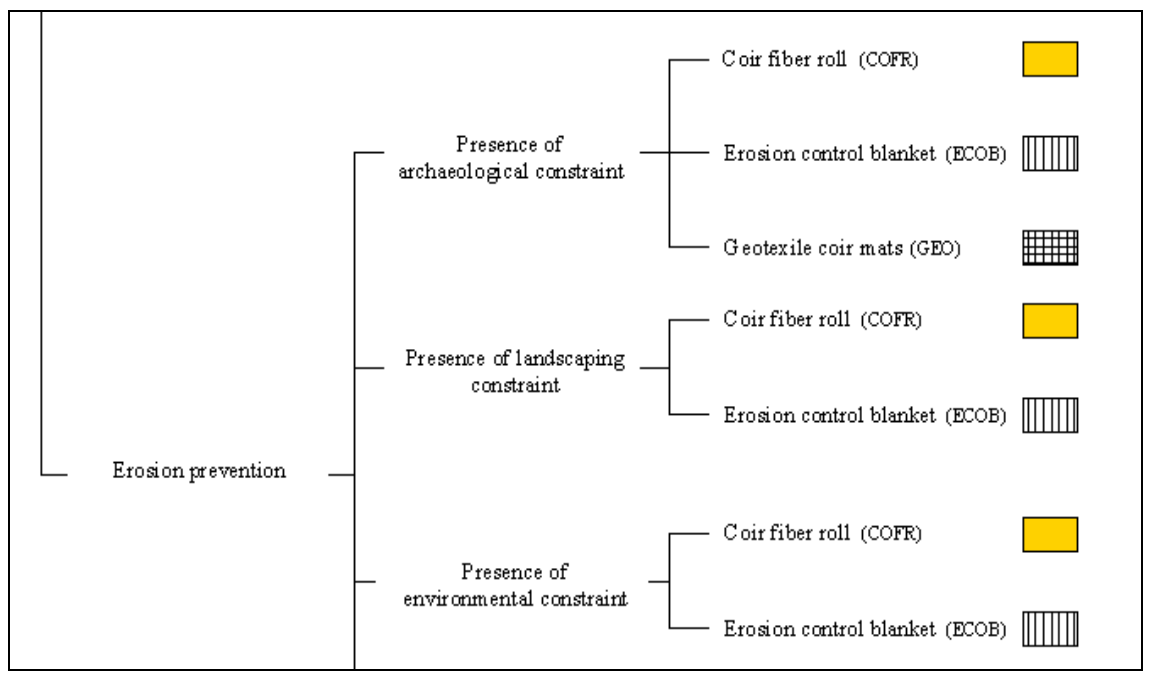

Figure 2: Detail of the diagram; different choices of works are related to the landscaping, environmental or archaeological restrictions present in each area.

\section{Coir fiber roll}

(COFR)

Description of work:

Figure 3: Detail of the technical card concerning Coir fiber roll; on the right side the link to the diagram.

\section{References}

[1] Regione Lazio, Assessorato per l'Ambiente, Dipartimento Ambientale e Protezione Civile, Roma. Manuale di Ingegneria Naturalistica applicabile al settore idraulico. 2002.

[2] Ministero dell'Ambiente e della Tutela del Territorio; Ministero dell'Economia e delle Finanze; PODIS (Progetto operativo difesa del suolo). Manuale di indirizzo delle scelte progettuali per interventi di ingegneria naturalistica. 2005.

[3] University of Washington (UW), College of Forest Resource, http://depts.washington.edu/propplnt/Chapters/erosioncontrolchapter\%5B $1 \% 5$ D.pdf

[4] Agenzia per la Protezione dell'Ambiente e per i servizi Tecnici (APAT), Atlante delle opere di sistemazione fluviale. 2003. 
[5] Ministero dell'Ambiente e della Tutela del Territorio. Criteri e tecniche per la manutenzione del territorio ai fini della prevenzione del rischio idrogeologico. 2002.

[6] Agenzia per la Protezione dell'Ambiente e per i servizi Tecnici (APAT), Dipartimento di Difesa del Suolo. Atlante delle opere di sistemazione dei versanti. 2002.

[7] Da Deppo L. Casse d'espansione fluviali. Aspetti costruttivi. La difesa idraulica dei territori fortemente antropizzati. Editoriale BIOS. 1997.7

[8] Regione Piemonte, Direzione Difesa del Suolo, Manuale tecnico per la costruzione e gestione degli sbarramenti ed invasi di competenza regionale. Dighe e Invasi, 2005.

[9] Leoni B., Forasacco E., Dobner R. and Cotta Ramusino M.. River restoration and biocoenoses improvement in two streams renaturated using bioengineering. European Geophysical Society. 2003.

[10] Agenzia Nazionale per la Protezione dell'Ambiente (ANPA), Dipartimento Prevenzione e Risanamento Ambientale, Linee guida per la ricostruzione di aree umide per il trattamento di acque superficiali. Manuali e linee guida. 2002. 